\title{
THE EFFECT OF USNIC ACID ON LIVER CELLS
}

\author{
Eman M. Shaban ${ }^{(1)}$; Mahmoud A. Hewehy ${ }^{(1)}$; Amany M. Maher ${ }^{(2)}$ \\ and Nancy S. Wahba ${ }^{(3)}$
}

1) Institute of environmental studies \& Research, Ain-Shams University

2) Cell Culture and Molecular Biology Unit, Institute of Medical Research (MASRI), Ain Shams University 3) Clinical Pathology Department, Faculty of Medicine, Ain Shams University

\begin{abstract}
Usnic acid (UA), a natural botanical product, is a constituent of some dietary supplements used for weight loss. It has been associated with clinical hepatotoxicity leading to liver failure in humans. The present study was undertaken for metabolism and toxicity evaluations of (+)UA on HepG2 cell line in culture. The cells were treated with the vehicle control and $(+) \mathrm{UA}$ at concentrations of $0-100 \mu \mathrm{M}$ for $24 \mathrm{~h}$ at $37^{\circ} \mathrm{C}$ in $5 \% \mathrm{CO} 2$ incubator. Following the treatment period, the cells were evaluated by biochemical and toxicogenomic endpoints of toxicity that included MTT activity, LDH release. (+)UA exposure resulted in increased cytotoxicity and mitochondrial dysfunction in HepG2 cells. compared with the controls, low non-toxic concentrations of UA separately showed no effect on the cells as determined by the biochemical endpoints compared with higher concentrations $(\mathrm{P}<0.001)$.
\end{abstract}

Key words: usnic acid; dietary supplement; hepatotoxicity; liver toxicity; liver cells HepG2cells. 


\section{INTRODUCTION}

Usnic acid (UA) is a prominent metabolite of Usnea lichen species. Extracts of Usnea species and purified (+)UA are constituents in a variety of products worldwide that are used for antimicrobial, antiviral, antiparasitic, antimycotic, and antiproliferative purposes (Guo et al., 2008). However, the mechanisms of action of these effects have not been well specified. Despite the limited pharmacological characterization, (+)UA extracts and pure (+)UA have been marketed in the United State as dietary supplements, aiding in weight loss due to the ability of (+)UA to increase fat metabolism and increase the basal metabolic rate. Unfortunately, acute liver failure has occurred in humans taking pure (+)UA or (+)UA-containing products ( Yellapu et al., 2011). The U.S. Food and Drug Administration (FDA) issued a warning on using (+)usnic acid as dietary supplements, citing one specific product, LipoKinetix (CF-SAN, 2001a,b). Despite the reported adverse health effects, (+)usnic acid is still available in the market in various formulations. So far, studies on the mechanisms underlying (+)usnic acid toxicity are limited to a number of reports, mainly focused on mitochondrial impairment and oxidative stress ( Sahu et al., 2010; Sonko et al., 2011).

Development of alternative in-vitro assays is necessary for rapid, costeffective and high-throughput toxicological screening and characterization of compounds to complement and/or supplement the costly and time-consuming in vivo animal tests. Human cell cultures are sensitive tools for such highthroughput toxicity testing. They have the "potential to eliminate the need for interspecies extrapolation, to increase efficiencies in testing and to reduce the 
use of animals when used in combination with traditional biochemical endpoints (Meek and Doull, 2009).

Human hepatoblastoma HepG2 cells have been well characterized and are widely used as an in-vitro model (Fang and Beland, 2009). These cells are highly differentiated and display many genotypic and phenotypic features of normal liver cells. They preserve many of the cellular functions found in normal hepatocytes (Roe et al., 1993) and can be grown indefinitely for long term studies. These cells have been used in many toxicity studies for the screening of hepatotoxic compounds (Jennen et al., 2010). Compared with primary hepatocytes, they have low levels of phase I cytochrome P450 enzymes (Hewitt and Hewitt, 2004), but they have normal levels of phase II enzymes (Westerink and Schoonen, 2007). HepG2 cells have been used to classify $70 \%$ of compounds with known toxicity as cytotoxic (Schoonen et al., 2005b). The cytotoxicity of compounds is determined in HepG2 cells with $80 \%$ sensitivity and $90 \%$ specificity (O'Brien et al., 2006). HepG2 cells have been used to determine genotoxic and nongenotoxic carcinogens. These studies have demonstrated that, despite known limitations, HepG2 cells represent a valuable in vitro model for hepatotoxicity studies (Jennen et al. 2010).

The use of $(+) \mathrm{UA}$ and (+)UA-containing products is associated with acute liver failure; however studies on the mechanisms of hepatotoxicity are limited. From that prospective, we evaluated the metabolic effect and hepatotoxic potential of UA on HepG2 cells using different endpoints. 


\section{MATERIALS AND METHODS}

The human hepatocellular carcinoma HepG2 cells used in this study were obtained from Vacesera passage 28. (+) UA (98\% pure), were purchased from Sigma Aldrich Chemical Co. (St Louis, MO, USA). Dulbecco's modified Eagle's medium $4 \%$ glucose, phosphate buffered saline (PBS), trypsin-EDTA solution and $0.4 \%$ trypan blue solution was purchased from Invitrogen Corporation (Grand Island, NY, USA). Fetal bovine serum was purchased from the Hyclone Labs (Lonza, USA). Dimethyl sulfoxide (DMSO) was purchased from Baker (Philipsburgh, NJ, USA). The sterile nonpyrogenic polystyrene cell culture flasks and plates were purchased from Corning (Corning, NY, USA) and Beckton Dickinson (Franklin Lakes, NJ, USA) respectively.

Preparation of Stock Solutions of the Test Agent: The stock solution of $(+) \mathrm{UA}$ was prepared in DMSO and then stored at $-20^{\circ} \mathrm{C}$. The dosing solutions were prepared by serial dilutions of the stock solution in the cell culture medium immediately before use.

Cell Culture: The HepG2 cells were cultured in Dulbecco's modified Eagle's medium containing $4 \%$ glucose and supplemented with $10 \%$ fetal bovine serum, 1\% modified Eagle's medium nonessential amino acids and 10mm HEPES buffer (Sahu et al., 2010). The cells were cultured in a saturating humidified atmosphere of $5 \% \mathrm{CO} 2$ in air at $37^{\circ} \mathrm{C}$. The culture medium was changed every 3-4days. The cultures were used within 28 passages after the cells were received.

Treatment of Cells with the Test Agent: When the cells had grown to 8090\% confluence, they were prepared for the experimental procedures. The 
cells were washed with $\mathrm{Ca} 2$ and $\mathrm{Mg} 2$ free HBSS and harvested from the $25 \mathrm{~cm} 2$ culture flasks by $0.05 \%$ trypsin-EDTA. A single cell suspension in the culture medium was obtained by repeated trituration. Cell counts and cell viability were determined by trypan blue dye using a hemocytometer. A single cell suspension in the culture medium at a density of $1 \times 104$ cells/ml was prepared by serial dilution and the cell suspension was added $(100 \mu 1$ per well) to transparent flat bottom 96 well plates. Cells were then incubated for $24 \mathrm{~h}$ in a saturating humidified atmosphere of $5 \%$ $\mathrm{CO} 2$ incubator at $37^{\circ} \mathrm{C}$. Then the cells were washed once with PBS. The dosing solutions $(0-100 \mu \mathrm{M})$ were prepared by serial dilutions of the stock solution in the cell culture medium immediately before use. The concentrations of the dosing solutions and the time of exposure were selected based on literature search (Venkataraman and Krishna, 1993).

The cells were exposed to (+) usnic acid at concentrations of $0-100 \mu \mathrm{M}$. The dosing solutions were added to the cells in 10 replicate wells $(100 \mu 1$ per well). The control cells received an equal volume of the vehicle containing $\operatorname{DMSO}(0.2 \%, \mathrm{v} / \mathrm{v})$. The cells were treated with the vehicle control and dosing solutions for $24 \mathrm{hrs}$ at $37^{\circ} \mathrm{C}$ in a saturating humidity atmosphere of $5 \% \mathrm{CO} 2$ in air. After $24 \mathrm{hrs}$ of treatment the cells were used for different endpoints. The test agent was studied in three independent experiments:

1-Trypan blue cell viability method (TB): Cell viability analysis is a useful tool in various experimental procedures, including those for tumor susceptibility, microbiological resistance, and spontaneous cell death after submission to different experimental conditions ( Puoci et al., 2012). It has been established that cell membrane integrity is a basic criterion for 
distinguishing dead from live cells (Kroemer et al.,2009). Thus, dyes capable of selectively penetrating the cytoplasm of dead cells have been widely used as vital dyes. The trypan blue (TB) method is a very common assay for evaluating cytotoxicity in experimental investigations where dead cells absorb TB into the cytoplasm because of loss of membrane selectivity, whereas live cells remain unstained (Tennant JR,1964). Thus, the relative number of dead and live cells is obtained by optical microscopy by counting the number of stained (dead) and unstained (live) cells using a Neubauer chamber ( Kim et al.,2011).

2-Cytotoxicity: Cytotoxicity is defined as the potential of a compound to induce cell death. Therefore, cell viability is an index of cytotoxicity. In the present study, the cytotoxicity of the test agents was measured (Sahu et al., 2008, 2010) using two independent methods: (a) MTT cell viability assay and (b) Lactate Dehydrogenase (LDH) release assay.

2-a) MTT cell viability assay: HepG2 cells were seeded into 96-well culture plates and were incubated in $37^{\circ} \mathrm{C}$ under a $5 \% \mathrm{CO} 2 / 95 \%$ humidified air incubator for $24 \mathrm{hrs}$. Cells were then incubated with (+)usnic acid at indicated concentrations in serum free Dulbecco's modified Eagle's medium ( DMEM )for an additional $24 \mathrm{~h}$. The compounds were dissolved in DMSO and the level of DMSO in treatments did not exceed $0.1 \%$. Cell viability was determined using the addition of $20 \mu \mathrm{l}$ of MTT 3-(4,5dimethylthiazol-2-yl)-2,5-diphenyl tetrazolium bromide) solution (5 $\mathrm{mg} / \mathrm{ml}$ ) to each well, which yields a blue formazan product in living cells, but not in dead cells or their lytic debris. Then, cells were washed with PBS and dissolved in $50 \mu \mathrm{l}$ DMSO. Absorbance was determined by 
microplate Reader at $540 \mathrm{~nm}$. The results were expressed as a percentage of MTT assay activity relative to the non-treated control. The 50\% inhibitory concentration, LC50's of the $(+)$ usnic acid was calculated, based on the concentration of treating compounds at which $50 \%$ cell alive compared to non-treated samples. The experiments were repeated three times independently (Johan et al., 2011).

2-b) Lactate dehydrogenase assay: The cytotoxicity of (+)usnic acid assessed using the lactate dehydrogenase (LDH) assay (Thermo Scientific), where cultured cells were incubated with (+)usnic acid to induce cytotoxicity and subsequently release LDH. The LDH released into the medium is transferred to a new plate and mixed with Reaction Mixture. After 30 minute room temperature incubation, reactions are stopped by adding Stop Solution. Absorbance at $490 \mathrm{~nm}$ and $680 \mathrm{~nm}$ is measured using a platereading spectrophotometer to determine $\mathrm{LDH}$ activity.

$\%$ Cytotoxicity $=$ Compound-treated LDH activity - Spontaneous LDH activity $\times 100$

Maximum LDH activity - Spontaneous LDH activity

\section{3-Biochemical study}

\section{3-a) Determination of transaminase activity (AST, ALT), ALP and $\chi G T:$}

Aliquot of $0.5 \mathrm{ml}$ cell suspension was centrifuged at $1000 \mathrm{rpm}$ for $1 \mathrm{~min}$, the supernatant was measured for transaminase activity (AST \& ALT) using the method of Reitman and Frankel (1957), while ALP was detected according to (Wenger et al., 1984) and $\gamma \mathrm{GT}$ according to (Gendler et al., 1984).

3-b) Determination of alfaphetoprotein (AFP).: Another aliquot of $0.5 \mathrm{ml}$ cell suspension was centrifuged at $1000 \mathrm{rpm}$ for $1 \mathrm{~min}$, the supernatant 
was collected to measure tumor marker AFP using the kit of ARCHITECT SYSTEM, from Abbott Laboratories.

4- Statistical Analysis: The biochemical endpoints data are presented as the mean \pm standard deviation (SD) of at least three independent experiments. Analysis was performed using SPSS v23. Statistical significance was determined by one-way analysis of variance (ANOVA)

\section{RESULTS}

The HepG2 cells were directly examined under Zeiss microscope to assess the effect of UA in different concentrations on the cell morphology, confluence and viability. Findings showed that US induced cytotoxic changes in HepG2 cells which increased by increasing UA concentration (Fig. 1).

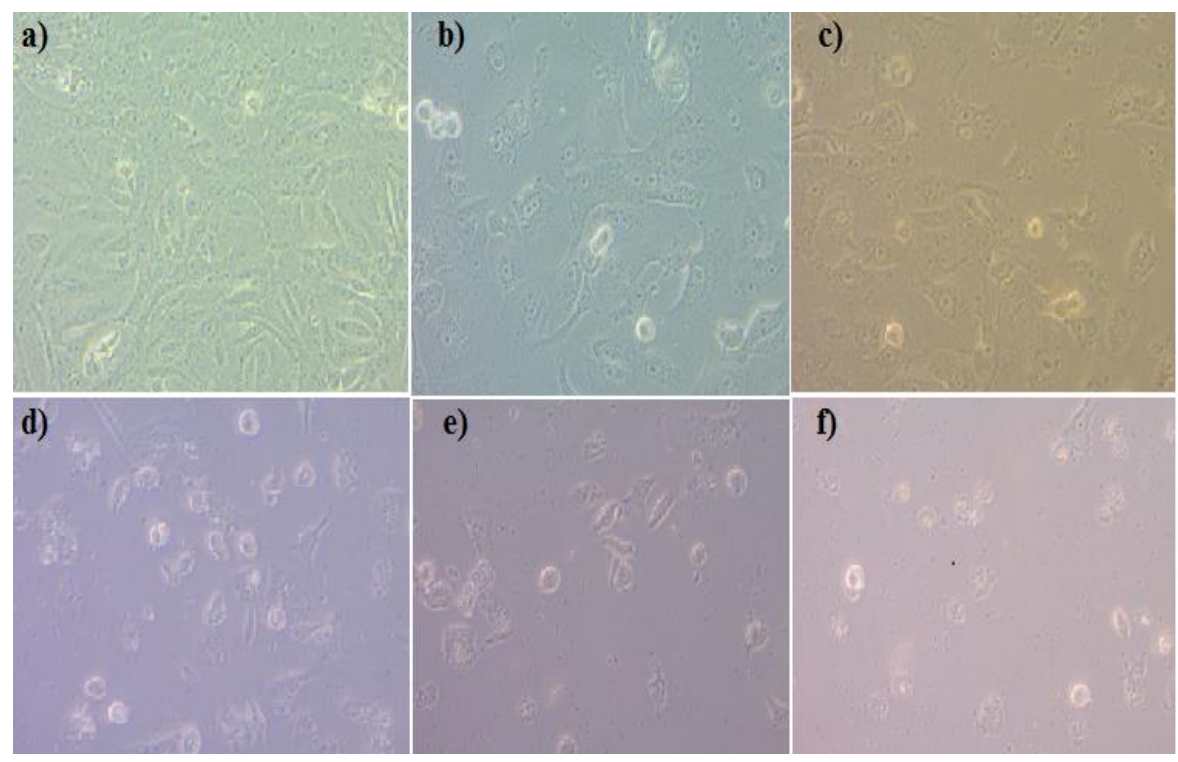


Figure(1): Morphological changes of human hepatoma (HepG2) cells in untreated control and chemical-treated HepG2 cells after treatment with various concentrations $(5,10,20,50$ and $100 \mu \mathrm{M})$ of (+)usnic acid for $24 \mathrm{hrs}$ incubation. (a) Showed control HepG2 cell line (100\%confleuence),(b) showed HepG2cells treated with $5 \mu \mathrm{M}$ Usnic acid Few floating cells dead and the majority of cell are attached(c)showed HepG2 cells treated with $10 \mu \mathrm{M}$ Usnic acid and few floating cells dead the majority of cell are attached but unhealthy with the presence of granules,(d)showed HepG2 cells treated with $20 \mu \mathrm{M}$ Usnic acid, presence of few attached cells and some cell contain nucleus but unhealthy with the presence of granules(e) showed HepG2 cells treated with $50 \mu \mathrm{M}$ Usnic acid - Presence of very few attached cells (like that of con $20 \mu \mathrm{M})$ - Some cell contain nucleus but unhealthy with the presence of granules and(f) showed HepG2 cells treated with 100 $\mu \mathrm{M}$ Usnic acid.

The effect of UA on HepG2 cell line viability was measured by Trypan Blue assay. Results showed gradual decrease in survival rate of HepG2 cell line with increasing concentration of UA exposure to HepG2 cell line (Fig.2). 


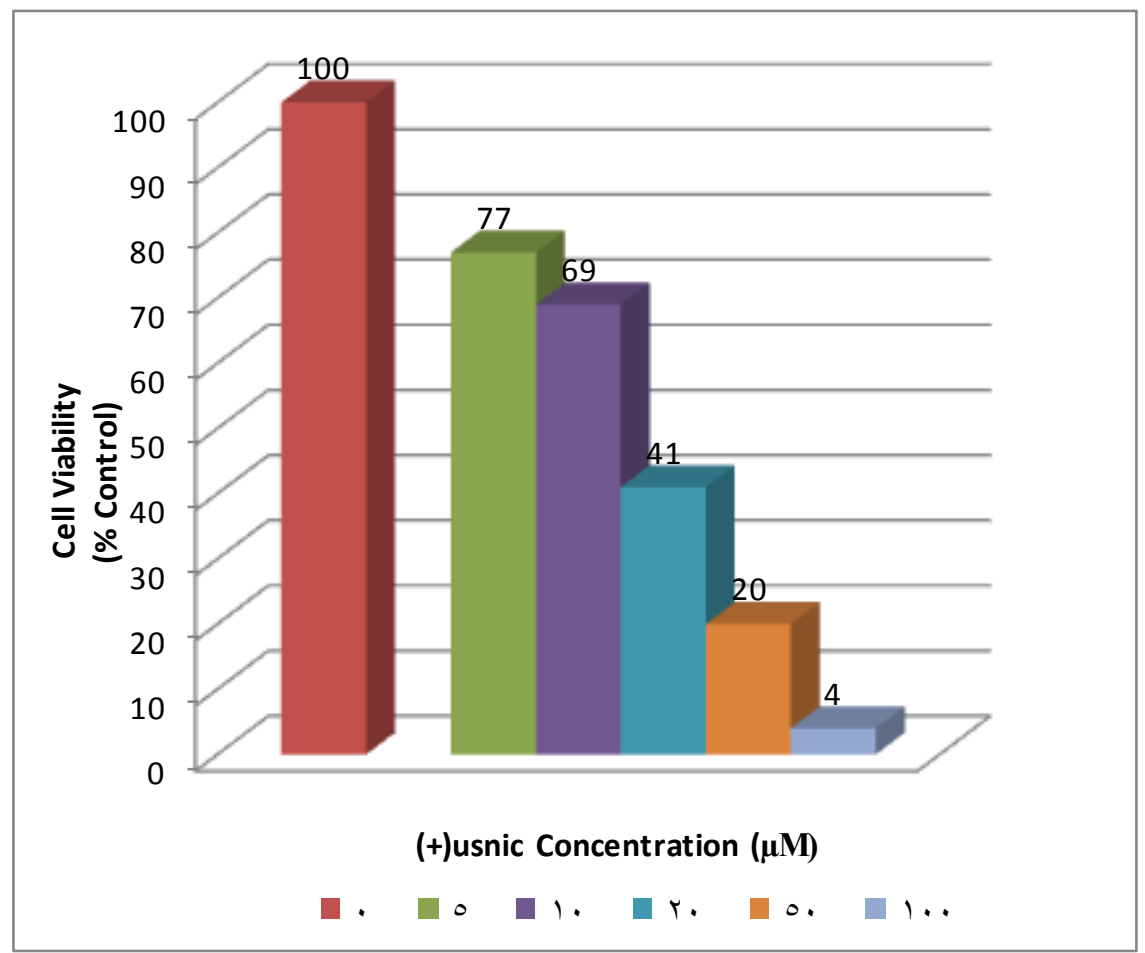

Figure(2): Effects of (+)usnic acid (UA) on cell viability measured by the Trypan Blue assay. Each value is the mean \pm SD of experiments from 10 replicates. *Significantly different from the control value $(\mathrm{P} \leq 0.05)$.

In addition, the cytotoxic effect of (+)UA on viability by human hepatoblastoma HepG2 cells in culture was evaluated using biochemical and cytotoxicity profile endpoints. After $24 \mathrm{~h}$ exposure of the HepG2 cells to (+)usnic acid, cytotoxicity was assessed using the MTT assay (to measure cell viability by the activation of mitochondrial succinate dehydrogenase in live cells) and the LDH assay (to measure LDH release from compromised cell membranes) in parallel. It was found that (+)usnic acid exhibited a 
J. Environ. Sci.

Institute of Environmental Studies and Research - Ain Shams University

concentration-dependent growth inhibiting effect as measured by the MTT assay. In addition, a significant increase in LDH release occurred after exposure to $(+) \mathrm{UA}$ at all concentrations tested, proving also the cytotoxic effect of UA. The 50\% inhibitory concentration LC50 was found to be 20.0 $\mu \mathrm{M}$ compared with the vehicle control (Fig.3).

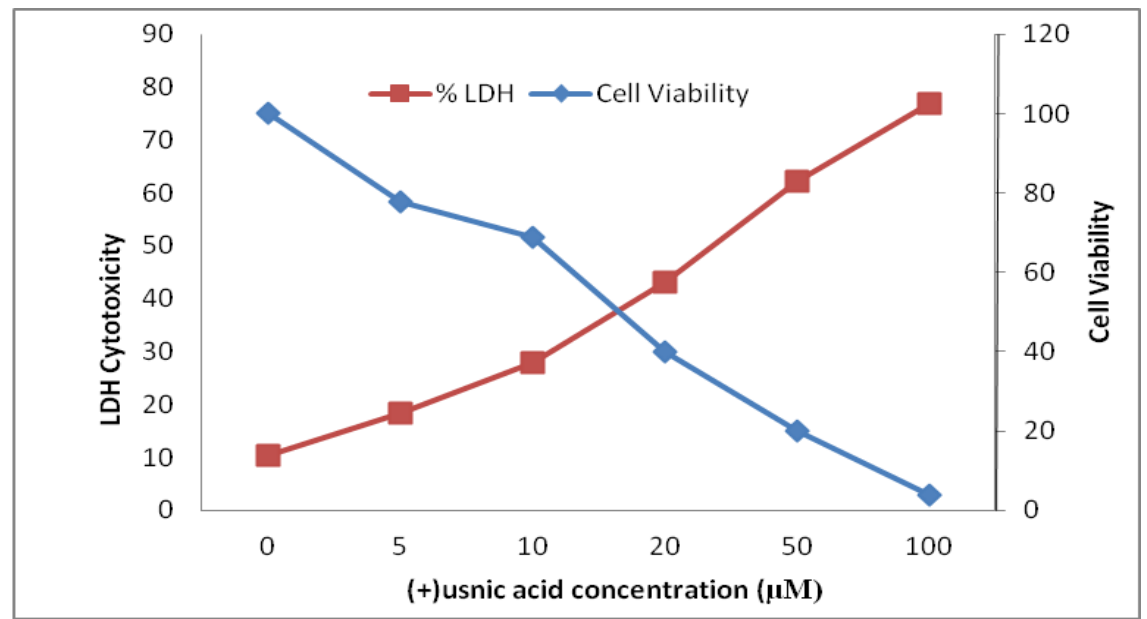

Figure(3): The dose response curve for the two assays employed when HepG2 cells were exposed to (+)usnic acid $(0-100 \mu \mathrm{M})$ for $24 \mathrm{hrs}$. (+)usnic acid causes cellular damage in HepG2 cells. HepG2 cells were exposed to increasing concentrations $(5,10,20,50$ and $100 \mu \mathrm{M})$ of $(+)$ usnic acid, with DMSO as the vehicle control for 24 h. (A) Cell viability was assessed using the MTT assay. (B) LDH release was determined as described under the Materials and Methods section; the results shown are mean \pm SD of at least three individual experiments.

Biochemical assays (for AST, Alt, ALP and GGT) were performed after $24 \mathrm{~h}$ of HepG2 cells treatment with different UA concentration. The study of Vol. 46, No. 3 Jun. 2019 
cytotoxic effect of $(+) \mathrm{UA}$ on HepG2 demonstrated the dose related pattern in the release of cellular transaminase (AST, ALT) and other enzymes (ALP and GGT). When increasing the dose of (+)usnic acid, levels of transaminase activity (AST, ALT) as well as Alp and $\gamma \mathrm{GT}$ released were increased, but with no significant change in low doses $(5$ and $10 \mu \mathrm{M})($ Table1) .

Table(1): Effects of 24h treatment of (+)usnic acid on serum AST , ALT , Alp and $\gamma \mathrm{GT}$

\begin{tabular}{|c|c|c|c|c|}
\hline \hline & Transaminasesa & & $\begin{array}{c}\text { Alkaline } \\
\text { Phosphatasea } \\
\text { ALP }\end{array}$ & $\square$ GTa \\
\hline \hline AST & ALT & & $\square$ \\
\hline Control & $9.2 \pm 4.0$ & $8.0 \pm 3.1$ & $62.8 \pm 3.3$ & $14.4 \pm 4.9$ \\
\hline $\begin{array}{c}(+) \text { Usnic acid } \\
5 \mu \mathrm{M}\end{array}$ & $7.08 \pm 1.7$ & $6.5 \pm 2.1$ & $62 \pm 3.5$ & $12.5 \pm 1.4$ \\
\hline $\begin{array}{c}\text { (+)usnic acid } \\
10 \mu \mathrm{M}\end{array}$ & $13.7 \pm 3.1^{*}$ & $27.5 \pm 5.4^{* *}$ & $62.6 \pm 2.9$ & $19.5 \pm 4.6$ \\
\hline $\begin{array}{c}(+) \text { usnic acid } \\
20 \mu \mathrm{M}\end{array}$ & $13.5 \pm 3.3^{*}$ & $32.8 \pm 6.7^{* *}$ & $72.7 \pm 5.4^{*}$ & $26.2 \pm 6.1^{*}$ \\
\hline $\begin{array}{c}(+) \mathrm{usnic} \text { acid } \\
50 \mu \mathrm{M}\end{array}$ & $35.4 \pm 5.2^{* *}$ & $61.3 \pm 15.1^{* *}$ & $80.4 \pm 4.7^{* *}$ & $26.4 \pm 4.5^{* *}$ \\
\hline $\begin{array}{c}(+) \mathrm{usnic} \text { acid } \\
100 \mu \mathrm{M}\end{array}$ & $40.4 \pm 5.9^{* *}$ & $77.9 \pm 14.3^{* *}$ & $87.4 \pm 4.2^{* *}$ & $27.6 \pm 4.5^{* *}$ \\
\hline \hline
\end{tabular}

${ }^{\mathrm{a}}$ Values are mean \pm S.D.

* Significantly different from control group $(\mathrm{p}<0.05)$.

** Highly Significantly different from control group $(\mathrm{p}<0.01)$.

Biochemical assay for AFP level was performed after $24 \mathrm{~h}$ of HepG2 cells treatment with different UA concentration. Results showed a highly significant decrease $(\mathrm{P}<0.001)$ in the levels of AFP in HepG2 cells treated with UA, as compared with that of controls. The cytotoxic effect of UA causes cell death with decrease in the AFP released (Table 2). 
J. Environ. Sci.

Institute of Environmental Studies and Research - Ain Shams University

Table(2): Effects of 24h treatment of (+)usnic acid on serum AFP.

\begin{tabular}{|c|c|}
\hline & AFPa \\
\hline Control & $473 \pm 54.8$ \\
\hline (+)Usnic acid $5 \mu \mathrm{M}$ & $367 \pm 58 *$ \\
\hline$(+)$ Usnic acid $10 \mu \mathrm{M}$ & $260.2 \pm 53.8^{* *}$ \\
\hline$(+)$ Usnic acid $20 \mu \mathrm{M}$ & $46 \pm 35.3 * *$ \\
\hline$(+)$ Usnic acid $50 \mu \mathrm{M}$ & $11.6 \pm 7.1 * *$ \\
\hline (+)Usnic acid100 $\mu \mathrm{M}$ & $0.62 \pm 0.89^{* *}$ \\
\hline
\end{tabular}

a Values are mean \pm S.D.

* Significantly different from control group $(\mathrm{p}<0.05)$.

** Highly Significantly different from control group $(\mathrm{p}<0.01)$.

\section{DISCUSSIONS}

Usnic acid is of herbals and defined HDS that has been associated with liver damage (Zhu and Kruhlak 2014).

Usnic acid extracted from lichens and fungi has been marketed as (herbal and dietery supplements)HDS in the USA to aid in weight loss. Efficacy for this indication was postulated based on its function as an uncoupler of the respiratory chain. Uncouplers of mitochondrial oxidative phosphorylation have gained attention as possible ingredients for weight loss supplements because they are believed to increase metabolic rates and stimulated fuel oxidation which in principle can augment weight loss (Moreira et al., 2013). However, it may also cause mitochondrial injury and subsequent hepatocyte death (Han et al., 2004)and several cases of acuteliver failurehave been reported requiring liver transplantation following the intake of these products for example Lipokinetix $\mathrm{R}$ a product containing sodium usneate (usnic acid) and sold as HDS capsules (Sanches et al., 2006). 
In vitro liver-derived cell lines have been used extensively in toxicity testing as an alternatives and complements to primary hepatocytes. Multiple hepatocytes derived cellular carcinoma cell lines, such as HepG2, Huh7, and HepaRG cells have been established over the years, and they display distinct characteristics regarding the expression and activity levels of drugmetabolizing enzymes and other hepatocyte specific factors (Ren et al., 2018).

The cytotoxicity assays employed revealed different profiles, were the MTT and the LDH assay The loss of intracellular LDH and its release into the culture medium is an indicator of irreversible cell death due to cell membrane damage, whereas the MTT assay is mainly based on the enzymatic conversion of MTT in the mitochondria showing statistically significant difference between the treated cells and the controls. The LDH assay revealed toxicity following the increase of concentrations of the (+)usnic acid. This observation can be explained by the nature of each assay.

HepG2 cells are well-differentiated hepatocarcinoma cells; they share the same morphological characteristics of liver parenchymal cells, and have been shown to retain liver-specific functions, such as plasma protein synthesis and secretion. It is the most frequently used hepatoma cell line in the testing and research of(drug induced liver injury) DILI, especially during the early screening of drug development. (Aden et al., 1979).

The present study was undertaken to evaluate the metabolism andtoxic effects of usnic acid human hepatoblastoma HepG2 cells in culture. The cells were treated with the vehicle control and usnic acid at concentrations of 0 
J. Environ. Sci.

Institute of Environmental Studies and Research - Ain Shams University

$100 \mu \mathrm{M}$ for $24 \mathrm{~h}$ at $37 \mathrm{C}$ in $5 \% \mathrm{CO} 2$. Following the treatment period,the cells were evaluated by viability, toxicity and biochemical parameters .

Our study morphological examination (using an inverted light microscope) showed that usnic acid with different concentrations $(5,10,20,50,100) \mu \mathrm{M}$-treated cells were clearly discerned by their rounded shapes compared to the polygonal shapes of untreated cells, suggesting possible growth-arresting and apoptosis-inducing effects of usnic acid.

This result showed cell shrinkage, membrane breakage and few cells were found to have detached from the plate and came to the medium as floating cells and Some cell contain nucleus but unhealthy with the presence of granules by increasing concentrations of usnic acid (5-10) $\mu \mathrm{M}$.

Cytotoxicity of Usnic acid on HepG2 cell line was assessed by MTT assay and LDH assay .The MTT showed a highly significant decrease $(\mathrm{p}<0.001)$ in the levels of MTT in HepG2 cells treated with different concentration of Usnic acid compared with that of controls, where IC50 was the concentration $20 \mu \mathrm{M}$ where $50 \%$ of the cells was dead. Where for LDH release table(4) and fig(20) showed a highly significant increase in LDH released from HepG2 cells treated with different concentration of Usnic acid compared with that of control, where cells ruptured and LDH is released $(\mathrm{p}<0.001)$.

These results are in agreement with the previous work on HepG2 cells in culture (Sahu et al.,2011). The exposure of these cells to usnic acid resulted in increased cytotoxicity, oxidativestress, mitochondrial dysfunction . Also, these results were in agreement with that of toxicity from other laboratories using different cell lines (Han et al., 2004; Pramyothin et al., 2004). Han et 
al. (2004) have reported UA-induced cytotoxicity and oxidative stress in primary mouse hepatocytes. Pramyothin et al. (2004) showed UA-induced cytotoxicity in primary rat hepatocytes.

Biochemical analysis in the present study included assays for AST, ALT, ALP, GGT, AFP assays the results of biochemical analysis showed that the lower levels of UA had no significant effect occured on HepG2 cells compared with the controls. However, by increasing usnic acid the concentration this showed increase in the toxic effect represented. After $24 \mathrm{~h}$ of treatment of (+)usnic acid in HepG2 cell line, there was significant change in serum transaminase activity (serum AST, ALT,ALP). The damage to cell membrane integrity that causes the release of cellular hepatospecific enzymes, mainly the transaminase (AST, ALT) (Pramyothin et al., 2004).Increased level of ALP may be due to hepatocyte injury which stimulates the synthesis of the enzymes.

With respect to AFP which is a carcinoembryonic protein and a very important marker of primary hepatocellular carcinoma,our study showed a highly significant depression $(\mathrm{p}<0.001)$ in the levels of AFP in HepG2 cells treated with different concentration of Usnic acid compared with that of controls, as the malignant cells die the amount of AFP released decrease table(5)and fig(21).

High $\gamma$-GT activity is also a marker of hepatocarcinoma: its activity is extremely low in the adult liver and gradually increases during the oncogenesis of liver cancer.The present study showed a highly significant depression $(\mathrm{p}<0.001)$ in the levels of $\gamma \mathrm{GT}$ in HepG2 cells treated with 
J. Environ. Sci.

Institute of Environmental Studies and Research - Ain Shams University

different concentration of Usnic acid compared with that of controls table (9)and fig(24).

These results agree with study of Harmful effects of usnic acid on hepatic metabolism (Moreira et al.,2013) on livers of male Wistar rats and agree with a case study of (Hsu et al.,2005) Fat Burner' Herb, Usnic Acid, Induced Acute Hepatitis In A Family.

\section{CONCLUSION}

The present study highlighted the cytotoxic effect of UA on HepG2 cells in culture. Exposed cells to UA at different concentrations showed decreased cell viability and survival that were measured by cytotoxicity and biochemical assays. All the assays done in the present study proved the potential harmful side effects of UA on human hepatocytes. In addition ,the results in the study highlights the benefits of HepG2 cells in culture and its promising predictive power in identifying the DILI risks. HepG2 cells may represent a sensitive in vitro system for use in high throughput screening of food borne agents for their potential hepatotoxic effects and together with studying of gene expression profiles and biochemical analysis, will serve as a useful tool to understand the mechanisms and pathways of toxicity.

\section{REFERENCES}

Aden, D.P.; Fogel, A.; Plotkin, S.; Damjanov, I. and Knowles, BB.: Controlled synthesis of HBsAg in a differentiated human liver carcinoma-derived cell line. Nature ,282(5739), (1979), 615-616.

CF-SAN (2001a): FDA Warns Consumers Not to Use the Dietary Supplement 
LipoKinetix.http://www.fda.gov/Safety/MedWatch/SafetyInforma tion/SafetyAlertsforHumanMedicalProducts/ucm172824.htm

CF-SAN (2001b): Letter to Distributor on Hazardous Dietary Supplement LipoKinetix.http://www.fda.gov/Safety/MedWatch/SafetyInforma tion/SafetyAlertsforHumanMedicalProducts/ucm174455.htm

Fang, J. and Beland, F.A.: Long-term exposure to Zidovudine delays cell cycle progression, induces apoptosis and decreases telomerase activity in human hepatocytes. Toxicol Sci; 111: (2009), 120-130.

Gendler, E.; Gendler, S. and Nimni, E: Toxic reaction evoked by glutaraldehyde-fixed pericardium and cardiac valve tissue bioprosthesis. J Biom Mat Res ;18: (1984) 727-736.

Guo, L.; Shi, Q.; Fang, J.L.; Mei, N.; Ali, A.A.; Lewis, S.M.; Leakey, J.E. and Frankos, V.H.: Review of (+) usnic acid and Usnea barbata toxicity. J Environ Sci Health C Environ Carcinog Ecotoxicol Rev; 26: (2008), 317-338.

Han, D.; Matsumaru, K.; Rettori, D. and Kaplowitz, N. (2004): (+) usnic acid-induced necrosis of cultured mouse hepatocytes: Inhibition of mitochondrial function and oxidative stress. Biochem Pharmacol ; 67:439-451.

Hewitt, N.J. and Hewitt, P. (2004): Phase I and II enzyme characterization of two sources of HepG2 cell lines. Xenobiotica; 34: 243-256.

Hsu ,LM.; Huang, YS.; Chang, FY. and Lee, SD: 'Fat Burber' herb, usnic acid induced acute hepatitis in a family. Journal of gastroenterology and Hepatology; 20(7), (2005), 1138-9.

Jennen, D.G.; Magkoufopoulou, C.; Ketelslegers, H.B.; van Herwijnen, M.H.; Kleinjans, J.C. and van Delft, J.H. (2010): Comparison of HepG2 and HepaRG by whole genome gene expression analysis for the purpose of chemical hazard identification. Toxicol Sci; 115:6679.

Johan, vM.; Gertjan, J.L. and Jacqueline, C. (2011): Cancer Cell Culture: Methods and Protocols, 2nd Edn. Methods in Molecular Biology, Cell Sensitivity Assays, vol. 731:237-245.

Kim, J.S.; Nam, M.H.; An, SS.; Lim, C.S.; Hur, D.S.; Chung, C. et al: Comparison of the automated fluorescence microscopic viability test with the conventional and flow cytometry methods. J Clin Lab Anal ; 25: (2011), 90-94, doi: 10.1002/jcla.20438. 
Krishna, D.R.; Ramana, D.V. and Mamidi, N.V. (1995): Protein binding and tissue dis- tribution of $\mathrm{D}(+)$ isnic acid. Drug Metab. Drug Interact. 12:53-63.

Kroemer, G.; Galluzzi, L.; Vandenabeele, P.; Abrams, J.; Alnemri, ES.; Baehrecke, EH. et al.(2009): Classification of cell death: recommendations of the Nomenclature Committee on Cell Death. Cell Death Differ ; 16: 3-11.

Meek, B. and Doull, J. (2009): Pragmatic challenge for the vision of toxicity testing in the 21 st century in a regulatory context: Another Ames test? or a new edition of "the red book"? Toxicol Sci; 108: $190 \hat{u} 21$.

Moreira, CT.; Oliveira, AL.; Comar, JF.; Peralta, RM. and Bracht, A. (2013): Harmful effects of usnic acid on hepatic metabolism. Chemicobiological; 203(2):502-11.

O'Brien, P.J.; Irwin, W.; Diaz, D.; Howard-Cofield, E.; Krejsa, C.M.; Slaughter, M.R.; Gao, B.; Kaludercic, N.; Angeline, A. and Bernardi, P. (2006): High concordance of drug-induced human hepatotoxicity with invitro cytotoxicity mea- sured in a novel cellbased model using high content screening. Arch Toxicol; 80: 580-604.

Pornpen, P.A. ; Withaya, J.A.; Nushjira, P.B.; Siriwan, P. and Nijsiri,R.: Hepatotoxic effect of (+)usnic acid from Usnea siamensis Wainio in rats, isolated rat hepatocytes and isolated rat liver mitochondria. Journal of Ethnopharmacology; 90: (2011), 381387.

Pramyothin, P.; Janthasoot, W.; Pongnimitprasert, N.; Phrukudom, S. and Ruangrungsi, N: Hepatotoxic effect of (+)usnic acid from Usnea siamensis Wainio in rats, isolated rat hepatocytes and isolated rat liver mitochondria. J Ethnopharmacol ; 90: .(2004), 381-387.

Puoci, F.; Morelli, C.; Cirillo, G.; Curcio, M.; Parisi, OI.; Maris, P. et al.(2012): Anticancer activity of a quercetin-based polymer towards HeLa cancer cells. Anticancer Res; 32: 2843-2847.

Reitman, S. and Frankel, S: A colorimetric method for the determination of serum glutamic oxalacetic and glutamic pyruvic transaminases. American Journal of Clinical Pathology; 28: (1957), 56-6.

Ren, Z.; Chen, S.; Ning. B, and Guo , L.(2018): Use of Liver-Derived Cell Lines for the Study of Drug-Induced Liver Injury. Minjun Chen 
and Yvonne Will (eds.), Drug-Induced Liver Toxicity, Methods in Pharmacology and Toxicology, (C) Springer Science+Business Media, LLC, part of Springer Nature : 151-176.

Roe, A.L.; Snawder, J.E.; Benson, R.W.; Roberts, D.W. and Casciano, D.A. (1993): HepG2 cells: an invitro model for P45-dependent metabolism of acetaminophen. Biochemical Biophysics Research Community; 190:15-19.

Sahu, S.C.; Garthoff, L.H.; Robl, M.G.; Chirtel, S.J.; Ruggles, D.I.; Flynn, T.J. and Sobotka, T.J. (2008): Rat liver clone-9 cells in culture as a model for evaluating hepatotoxic potential of food-related products: Hepatotoxicity of deoxynivalenol. J Appl Tox; 28: 765772.

Sahu, S.C.; O'Donnell, M. and Wiesenfeld, P. (2010): on HepG2 cells and for 60 compounds on HeLa, ECC-1 and CHO cells. II mechanistic assays on $\mathrm{NAD}(\mathrm{P}) \mathrm{H}$, ATP and DNA contents. Toxicol Invitro; 19: 491-503.

Sanchez, W. ; Maple, J.; Burghardt, L. and Kamath, PS. (2006): Severe hepatotoxicity associated with use of a dietary supplement containing usnic acid. Mayo Clinic Proc; 81 : $541-544$.

Schoonen, W.G.; Westerink, W.M.; de Roos, J.A. and Debiton, E. (2005b): Cytotoxic effects of 100 reference compounds on Hep G2 and HeLa cells and of 60 compounds on ECC-1 and CHO cells. I mechanistic assays on ROS, glutathione depletion and calcein uptake. Toxicol Invitro; 19: 505-516.

Sonko, B.J.; Schmitt, T.C.; Guo, L.; Shi, Q.; Boros, L.G.; Leakey, J.E. and Beger, R.D. (2011): Assessment of (+)usnic acid toxicity in rat primary hepatocytes using (1)(3)C isotopomer distribution analysis of lactate, glutamate and glucose. Food Chem Toxicol; 49:2968-2974.

Tennant, J. R. (1964): Evaluation of the trypan blue technique for determination of cell viability. Transplantation; 2(6): 685-694.

Venkataraman, D. and Krishna, D.R.: Pharmacokinetics of $\mathrm{D}(+)-(+)$ usnic acid in rabbits after intravenous administration. Eur. J. Drug Metab Phar- macokinet; 18: (1993), 161-163.

Wenger, C.; Kaplan,A.; Rubaltelli, F.F. and Hammerman, C. (1984) :Alkaline Phosphatase. In: Clinical Chemistry: Theory, Analysis and 
Correlation, Kaplan, L.A. and A.J. Pesce (Eds.). The C.V. Mosby Co., St. Louis, Toronto; Princeton, pp: 1094-1098.

Westerink, W.M. and Schoonen, W.G. (2007): Phase II enzyme levels in HepG2 cells and cryopreserved primary human hepatocytes and their induction in HepG2 cells. Toxicol. Vitro; 21: 1592-1602.

Yellapu, R.K.; Mittal, V.; Grewal, P.; Fiel, M. and Schiano, T.: Acute liver failure caused by 'fat burners' and dietary supplements: A case report and literature review. Can J Gastroenterol; 25: (2011), 157160.

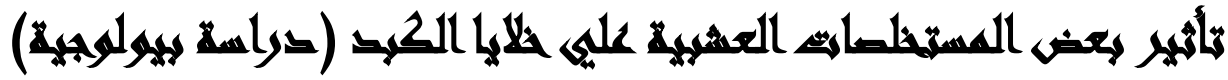

\section{[r]}

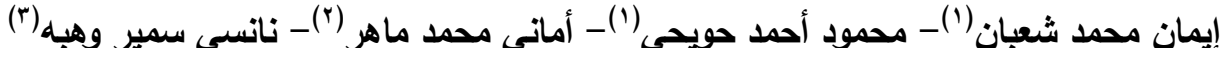

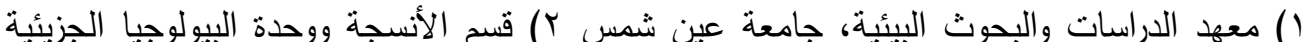

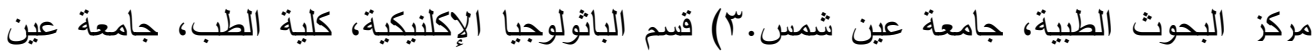

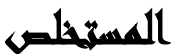

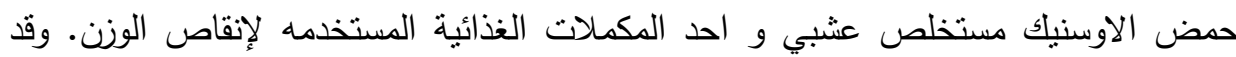

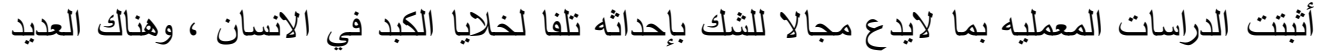

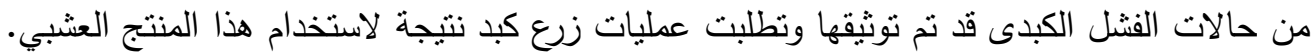

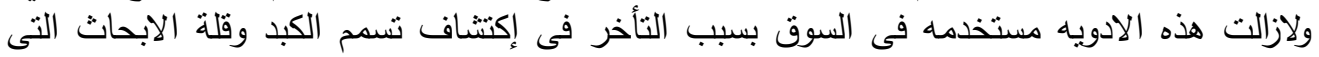
تشبته. وقد تم إدخال خط الخلايا الكبدية ذات الورم الأرومي في الابحاث لكي يكون نموذجاً مفيداً

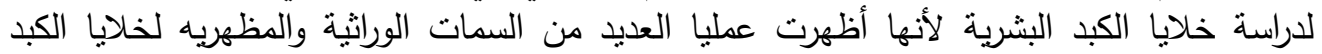

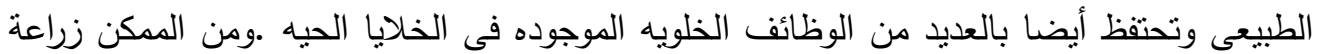

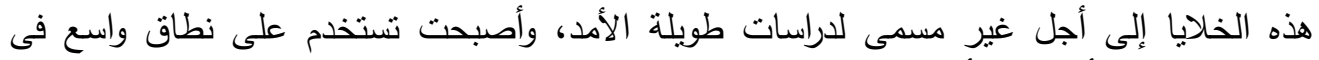
المختبرات لإجراءأبحاث التأثنيرات البيوكيميائيه و السمية على الخيات الخلايا الكبديه.

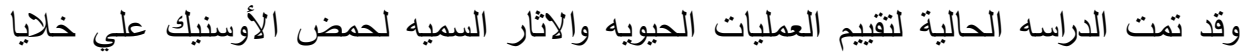

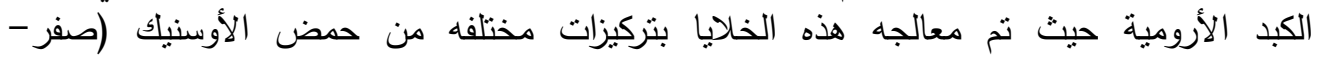

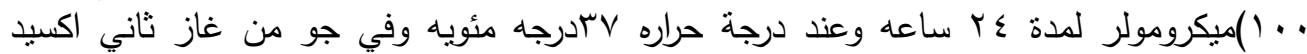
الكربون مشبع بنسبه 0\%، ثم تم تقييم حيوية الخلايا ودرجه السمية وعمل التحاليل البيوكيميائية.وقد 
أظهرت الفحوصات الميكروسكوبية لخلايا الكبد الارومية المعالجه بتركيزات مختلفه من حمض

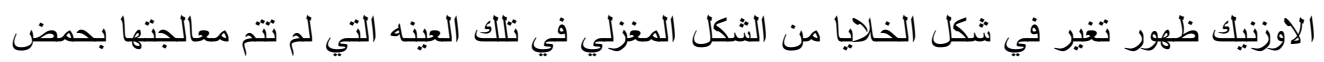

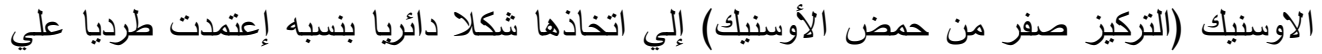

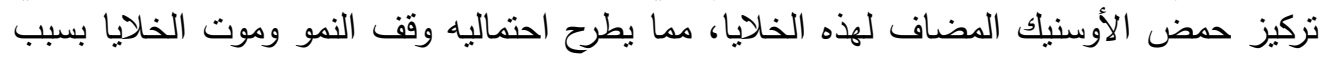

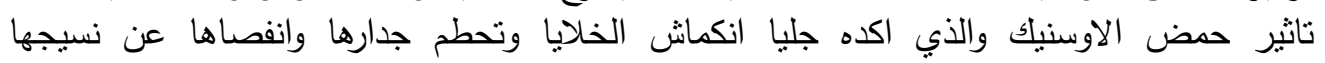

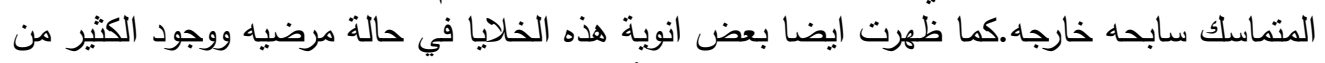

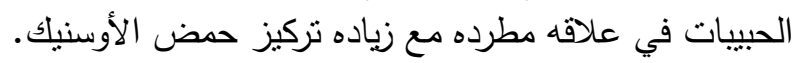

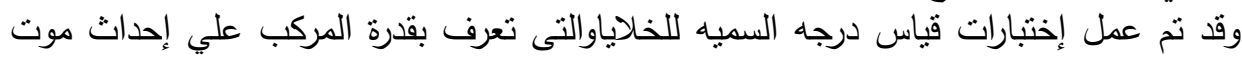

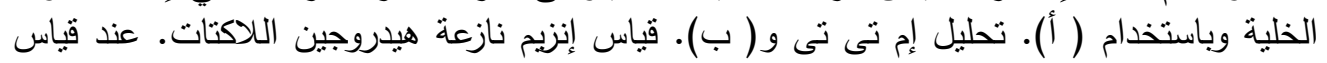

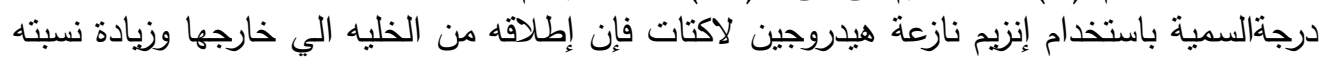

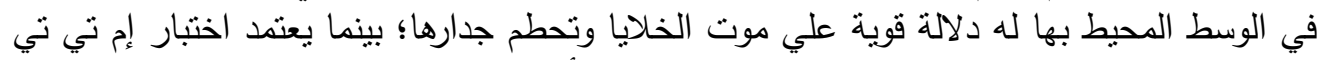

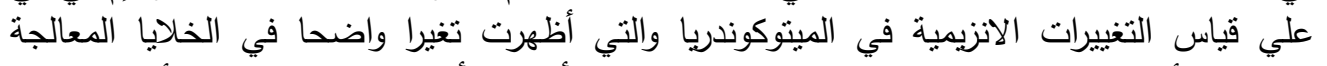

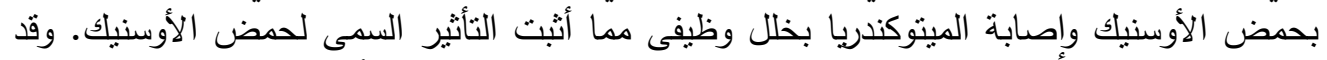

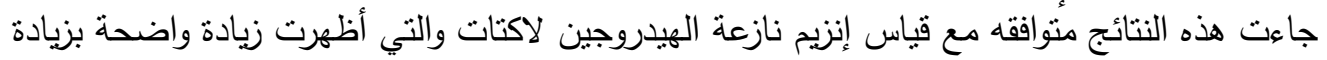

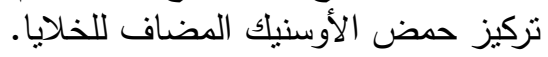

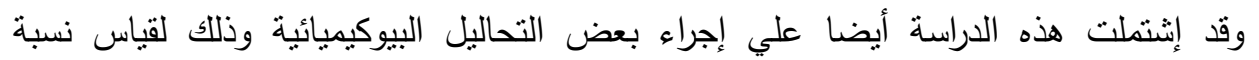

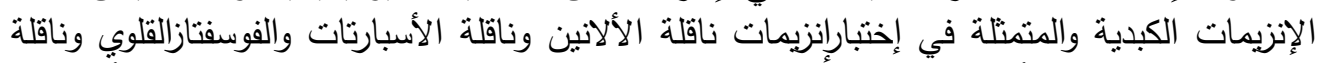

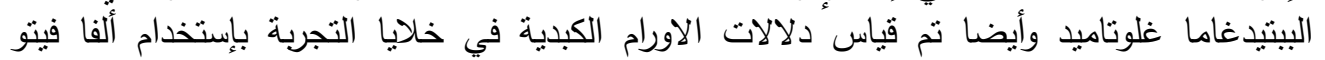

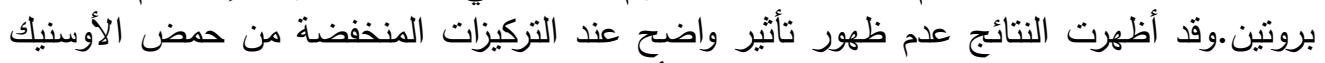

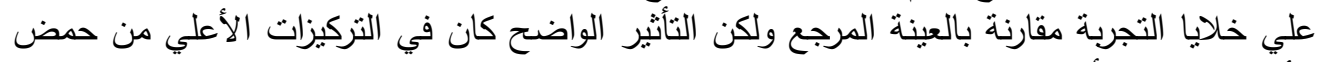

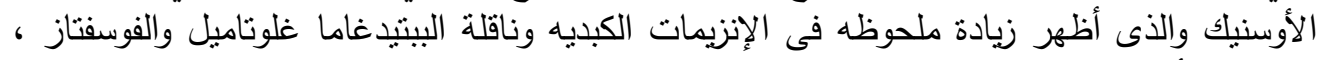

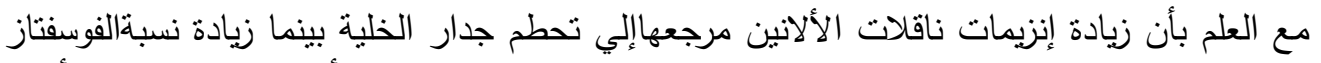

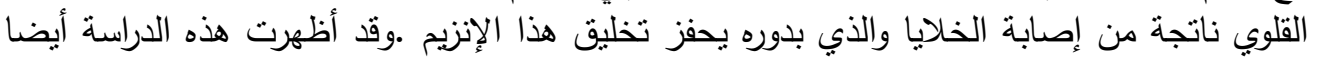

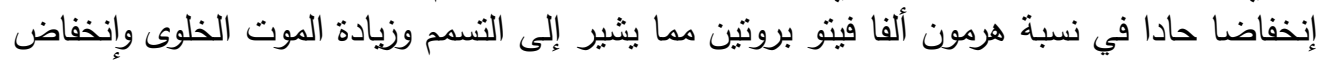

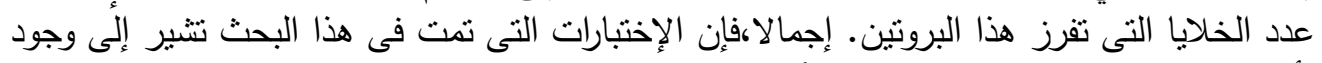

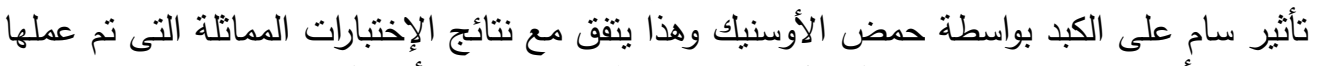

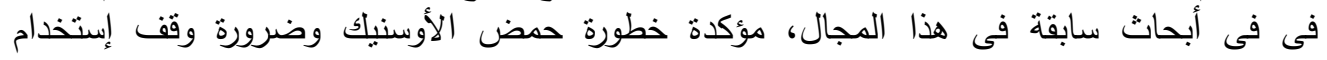

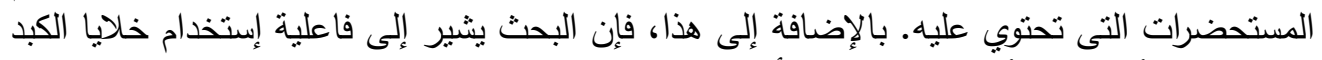

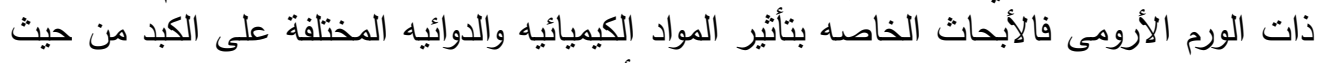

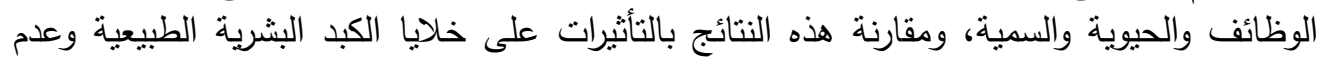

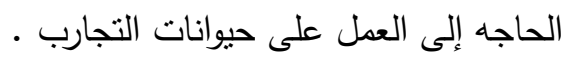
كلمات داله :حمض الإلى الإنيك; مكملات غذائية; تسمم الكبد ;خلايا الكبد 